\title{
EL LÁSER
}

\author{
NOGUERA $J^{1}$
}

En mayo de 1960, el físico estadounidense Theodore Harold Maiman consiguió, mediante un cristal de rubí, la emisión del primer impulso de luz coherente a partir de un láser. El término láser, acrónimo proveniente de la expresión inglesa «light amplification by stimulated emission of radiation», define un sistema de amplificación de luz por emisión estimulada de radiación con el que se obtienen haces de luz coherente, es decir, en la que todos los fotones se propagan en fase, oscilan a la par, creando interferencias constructivas y por lo tanto aumentando su amplitud, y obteniendo finalmente una emisión luminosa muy intensa, con muy poca dispersión y de un color muy puro.
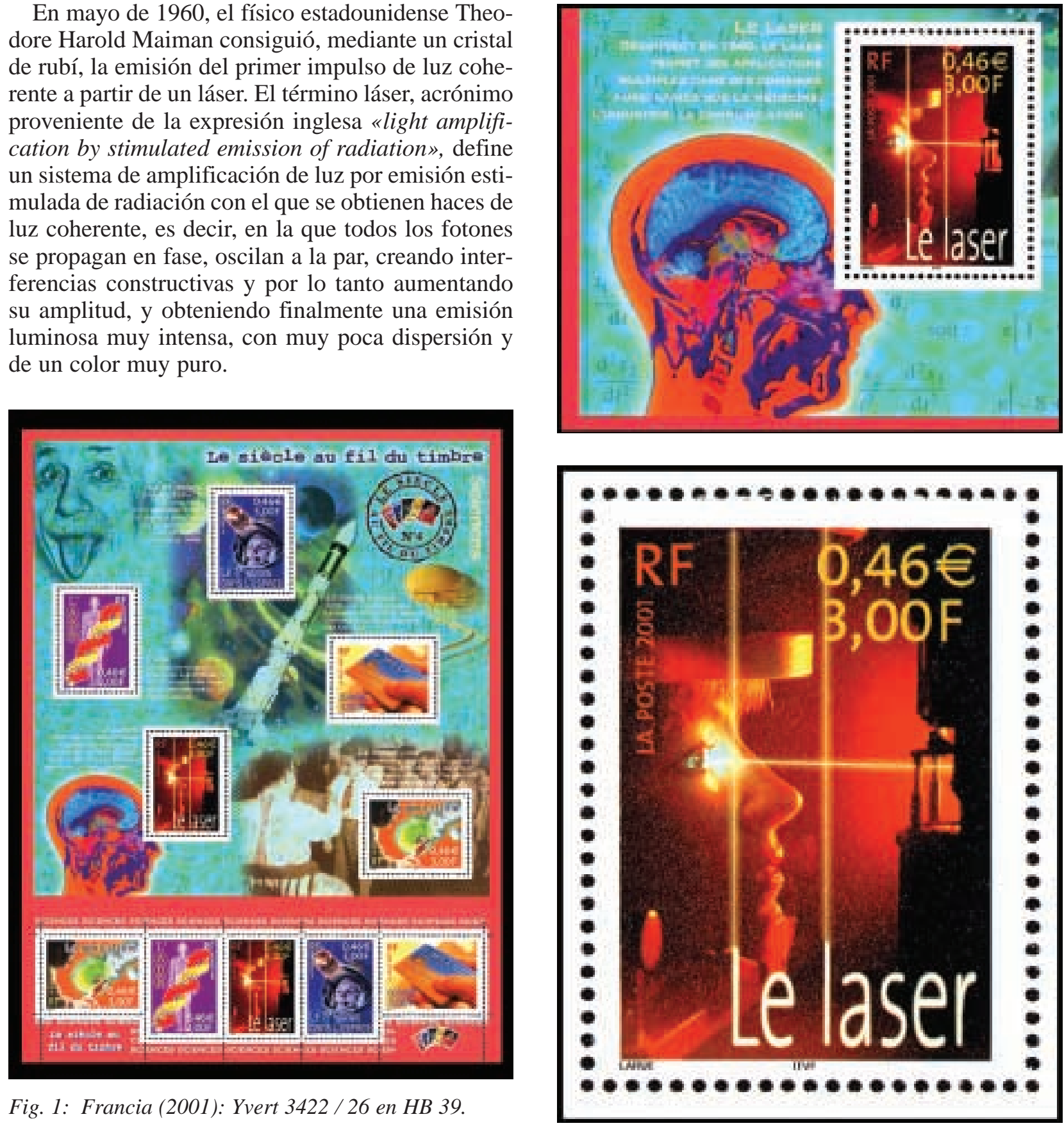

Fig. 1: Francia (2001): Yvert 3422 / 26 en HB 39.

${ }^{1}$ Oftalmólogo. Pamplona.

E-mail: JNOGUERA72B@terra.es 
Albert Einstein ya había descrito la emisión estimulada en 1917; en 1958, los físicos estadounidenses Arthur Schawlow y Charles Hard Townes obtuvieron la patente de un primer láser, la cual fue impugnada por otro compatriota, el físico e ingeniero Gordon Gould, y parcialmente reconocida por el Tribunal de Patentes de Estados Unidos en 1977.

Mientas tanto, Maiman ya había obtenido el primer impulso de láser en 1960, un año más tarde el iraní Ali Javan había construido un láser de helioneón y en 1966 el estadounidense Peter Soroquin había construido un láser líquido.
La primera aplicación en la oftalmología fue en 1963 por parte de H. C. Zweng, ayudado por el físico A. Vassiliadis, la bióloga Ann Hammond y el veterinario Jim Hayes. El primer receptor de un disparo de un láser de rubí sobre su retina fue un sufrido macaco rhesus.

Los correos franceses, por aquello del cambio de siglo, emitieron entre 2000 y 2002 un conjunto de sellos con la denominación común de «Le siècle au fil du timbre - El siglo a lo largo del sello»; en su cuarta emisión, dedicada a las ciencias, se incluyó un sello en el que una paciente es tratada con láser no sin peligro al no mantener la frente bien apoyada en la lámpara de hendidura. 